\section{Drawing Orders: Lines with/out Bodies}

Seray Türkay Coşkun¹, ORCID: 0000-0003-1696-7921

\section{Keywords}

drawing, line, order, representation, architecture

\section{Article Information}

\section{Abstract}

An investigation of architectural drawing offers a textual analysis of architecture and a critical perspective to discuss the architectural qualities established with(in) the drawing. Historically, drawing becomes prevalent as a disciplinary tool for architectural practice and research as long as its limitations are acknowledged and challenged. This paper recognizes fluctuating dispositions in architectural paradigm from drawing to withdrawing Orders. It traces the displacement of drawings constructed by lines with bodies with the drawings of lines without bodies to illustrate these dispositions. The study constructs a critical reading of the shifting meanings of "order" based on the theoretical and practical approaches to drawing. The drawings are used not merely as visual representations of architecture but rather as texts to provide a reading of lines as tools of constructing and de(con)structing orders in architecture. By drawings, how lines with/out bodies conceptualized order for different architectures and significantly determined their historiographies become visible.
Received: 09.07.2019

Accepted: 30.12.2019

Available Online: 28.01.2020

Article Info: This study was produced from the master's dissertation, titled "The Orthographic Set: Making Architecture Visible" at the Department of Architecture, Middle East Technical University.
1. Department of Architecture, TED University, Ankara, Turkey, seray.coskun@tedu.edu.tr 


\section{Düzenlerin Çizimi | Çizimin Düzenleri: Bedenli / Bedensiz Çizgiler}

Seray Türkay Coşkun¹, ORCID: 0000-0003-1696-7921

\section{Anahtar Sözcükler}

çizim, çizgi, düzen, temsil, mimarlık
$\ddot{O} z$

\begin{abstract}
Mimari çizim araştırması, mimarlık ve mimari çizimle birlikte tanımlanmış olan mimari niteliklerin üzerine eleştirel çözümlemeler sunar. Kısıtları tanınıp sorgulandığı takdirde çizim, mimarlık disiplini içerisinde araştırma ve uygulamanın tarihsel olarak en geçerli aracına dönüşmektedir. Bu çalışma, Düzenlerin çiziminden Düzenlerden çekilmeye doğru mimari paradigmalarda dalgalanan eğilimleri teşhis eder ve bu eğilimleri görselleştirmek için bedenli çizgilerle inşa edilen çizimlerin bedensiz çizgilerle yerinden edilmesinin izini sürer. Mimari çizime yönelik kuramsal ve uygulamalı yaklaşımlara dayanarak "düzen” kavramının değişen anlamları üzerine eleştirel bir okuma sunan araştırma, çizimleri mimarlığın salt görsel temsilleri olarak ele almaz. Çizimler, düzenleri kurmanın ve sökmenin araçları haline gelen çizgilerin okunabildiği metinler olarak kullanılmıştır. Bir diğer deyişle çizimler, düzenin farklı mimarlıklar için nasıl kavramsallaştırıldığını ve tarihselliklerinin nasıl tanımlandığını görünür k1lar.
\end{abstract}

Makale Bilgileri

Alındı: 09.07.2019

Kabul edildi: 30.12.2019

Erişilebilir: 28.01.2020

Makale Bilgisi: Bu çalışma, yazarın Orta Doğu Teknik Üniversitesi, Mimarlık Bölümünde yapmış olduğu, "Ortografik Set: Mimarlı̆g1 Görünür Kılmak” isimli yüksek lisans tezinden üretilmiştir.
1. Mimarlık Bölümü, TED Üniversitesi, Ankara, Türkiye, seray.coskun@tedu.edu.tr 


\section{INTRODUCTION}

Historicity of the discipline of architecture evolved around the engagement of drawing and design. Regarding the changing definitions that continuously refresh its conventions and representations, drawing has been historically the primary disciplinary tool in architecture. Architectural drawings seen as means to an end in the tradition of architecture have always been challenged by the idea that architecture always exceeds its representations. Yet the epistemological priority is always on the drawings, or rather on the imagined, on the projections yet to be realized. Historical and theoretical analyses in architecture have long been established on the discussions of drawing as the primary referent in the production of knowledge. Drawing and the reading performance it elicits are interpretive processes that produce new architectural entities beneath architectural realizations. In this particular realm of architecture without building, what orders architecture is the line.

Although the expression Drawing Orders denotes the orders of drawing as a technical construction, it essentially inheres the statement of Orders in architecture. What enables this powerful statement and which will in turn enables the destruction of this statement is mere drawing without building, and the line as the constituent of drawing. Line is accepted both as an agent to construct architectural bodies and as a bodily construction. The critical remark in the title Lines with(out) Bodies aims to reconsider the line as bodiless entity that shifts the reading of architectural drawing as a visual representation that orders and literally structures architecture into a criticism of architecture itself through lines without bodies. This paper aims at unfolding the dispositions in architectural paradigm from drawing to withdrawing Orders by tracing the displacement of drawings constructed by lines with bodies with the drawings of lines without bodies.

To illustrate the shifts in the meanings and practices of order, the drawings will be used not merely as visual representations of architecture but rather as texts to provide a reading of lines as tools of constructing and de(con)structing orders in architecture. Starting from Classical Orders, the prevalent approaches to drawing throughout the history of architecture are inquired. However, the aim is neither to rewrite history of drawing nor to evaluate the evolution of drawing. Although the presented practices drawing belong to outstanding figures in architectural history, a reading based on the changing meanings of order is provided through their lines and how they are conceptualized and operated to order different architectures is suggested. The ideas of specific figures, such as Vitruvius, Alberti, Palladio, Durand, Le Corbusier, and Eisenman, and how their ideas, concepts and terms become influential and operational in architectural drawing are critically acknowledged. The aim is to trace the hidden continuities and shifts of the term order in architectural paradigm 
over peculiar drawings and/or drawing practices. What is essential is the line either with or without a body.

\section{QUESTIONING ORDERS: LINES TO CONSTRUCT BODIES}

To understand what order meant for architecture, how it conceptualized, stylized, operated and embodied through lines, the origins of the use of the term is significant. For Vitruvius, the first codifier of architecture with his treatise entitled De Arcbitectura presenting immense quantity of traditional building lore in the first century BC, architecture firstly depends on order, which is called taxis ( $\tau \dot{\alpha} \xi \iota \varsigma)$ in Greek. It gives measure to the individual elements of a composition and determines the proportions within a whole. Alexander Tzonis and Liane Lefaivre choose to indicate this crucial concept with its Greek origin and state that Vitruvius defines taxis as the "balanced adjustment of the details of a work separately, and, as to the whole, the arrangement of the proportion with a view into a symmetrical result" (1986, p. 18). Using the term taxis instead of order is critical in the sense that both it abandons the confusion of order in architecture and Orders in architecture and it transforms the concept of order and ordering into a performative act, which can be operated visually.

The work of Tzonis and Lefaivre entitled Classical Architecture: The Poetics of Order presents a theoretical and analytical account for this research. The book inquiries into classical architecture and analyzes buildings as compositions visually, morphologically and stylistically. Following the idea of logos opticos (logic of composition), as Vitruvius did, they try to understand how classical architecture works as a formal system. With the clever introduction of the term "poetics" in their work's title, not merely as related with poetry but as a reference to all kinds of creative intellectual and manual production, Tzonis and Lefaivre render classical architecture as a creative production of order. Looking at the classical architecture as a composition logically produced through a creative processing under an order, they observe a canonic system within the composition of a classical building that operates through three levels of formal devices:

(1) taxis, which divides architectural works into parts; (2) genera, the individual elements that populate the parts as divided by taxis; and (3) symmetry, the relations between individual elements" (Tzonis and Lefaivre, 1986, p. 6).

What orders architecture in Classical architecture with its roots in antiquity, is taxis. Unfolding the definition of taxis is helpful to understand how it becomes operational in the conception and execution of a building in Classical Architecture. Tzonis and Lefaivre defines:

Taxis divides a building into parts and fits into the resulting partitions the architectural elements, producing a coherent work. In other words, taxis contains the placing of the architectural elements that populate a building by establishing successions of logically organized divisions of space (1986, p. 9). 

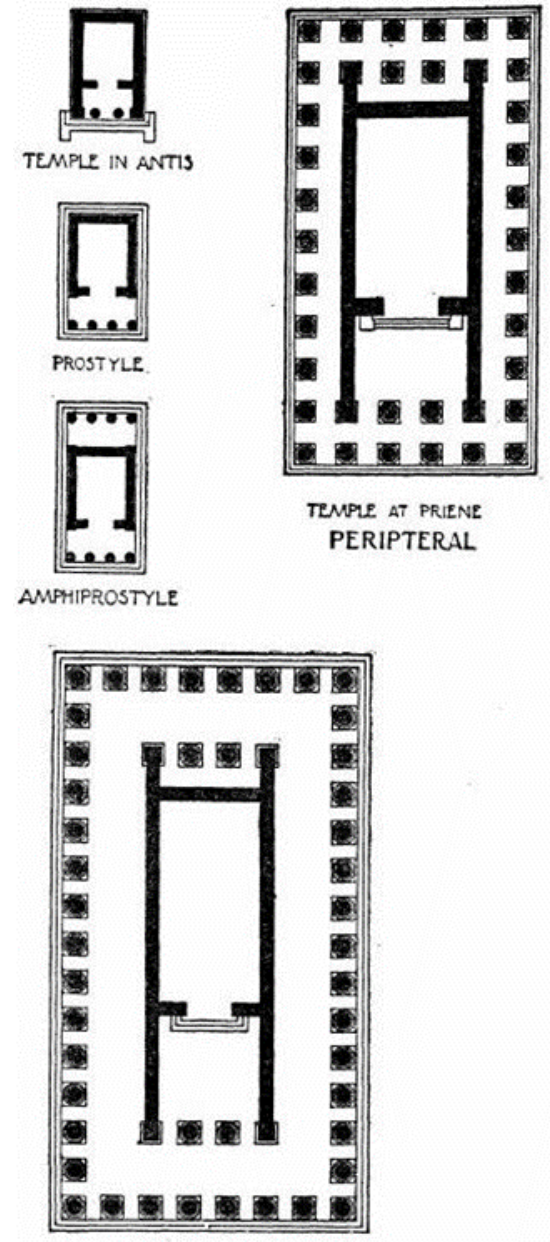

PSEVDODIPTERAL

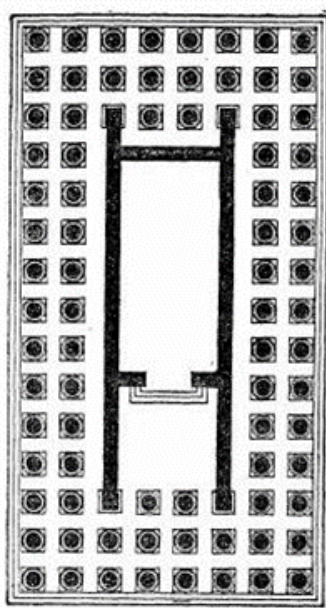

DIPTERAL

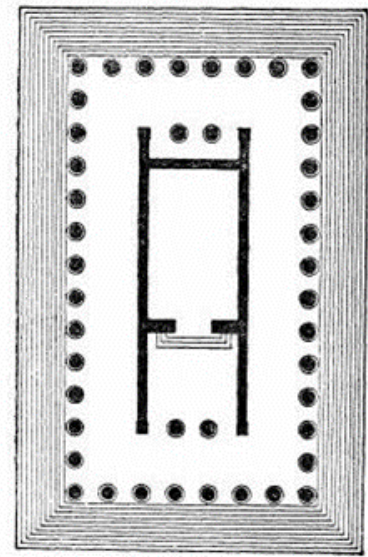

THE SMINTMEVM

Figure 1. Vitruvius' temple plans - "taxonomies": the classification of temples according to the arrangements of the colonnades based on "taxis" - the logic of partitioning. (Vitruvius, [First Century BC] 1960, Book III, Chapter II).

The act of dividing or partitioning is the key issue in the organization of a building. The architectural whole is basically regulated through the divisions. When it is divided into smaller and logical parts, the whole becomes controllable. Division defines everything from the basic components of the whole to elements that will compose these components, the distances between these elements and thus the relationships between the elements and the components. The result is an ordered whole with its specified proportions and measurements with a single operation that is division. The action of dividing is applicable in all scales varying from a temple to a column capital. Leon Battista Alberti used a more literal term to indicate division or partition, which is "partitio", translated as “compartition” by Joseph Rykwert, Neil Leach and Robert Tavernor (1988, p. 421) - a concept which treats building as a body that is decomposable to its parts, or rather bodily fragments, which are also individually articulated through partitio. The result is again a proportioned whole within which the "proportion" means the "successful combination of number, measure, and form" (Rykwert et al. 1988, p. 424) for Alberti. 
The logic of dividing and partitioning suggests an implicit method for proportioning and generating. The variety within compositions is achieved by the operation of taxis. The classification within compositions is also achieved by the operation of taxis. Simply, what generated and defined different kinds of temples, plans, columns, brick layouts, etc. was taxis, a basic operation of dividing. This is what makes the definition of "taxonomies" possible within Classical architecture.

Although Vitruvius has indicated the Greek origin of the term order, or in Latin ordinatio, as taxis, what taxis literally means is "arrangement." The processes of division and arrangement within taxis are intricate. It is impossible to separate division from arrangement since division includes the act of arrangement as well as arrangement includes the process of division. It is better to continue to use taxis as a comprehensive term to illustrate the process of this particular type of ordering. The particular elements composed as a result of the act of dividing is actually and simultaneously is arranged within the partitions. Individual considerations and articulations within elements always occur to enhance the elegance of the whole that is constructed through the process of taxis. 1800 years later, the most spectacular example that the notion of taxis becomes visible as the premise to the aesthetics would be the work of Jean-Nicolas-Louis Durand.

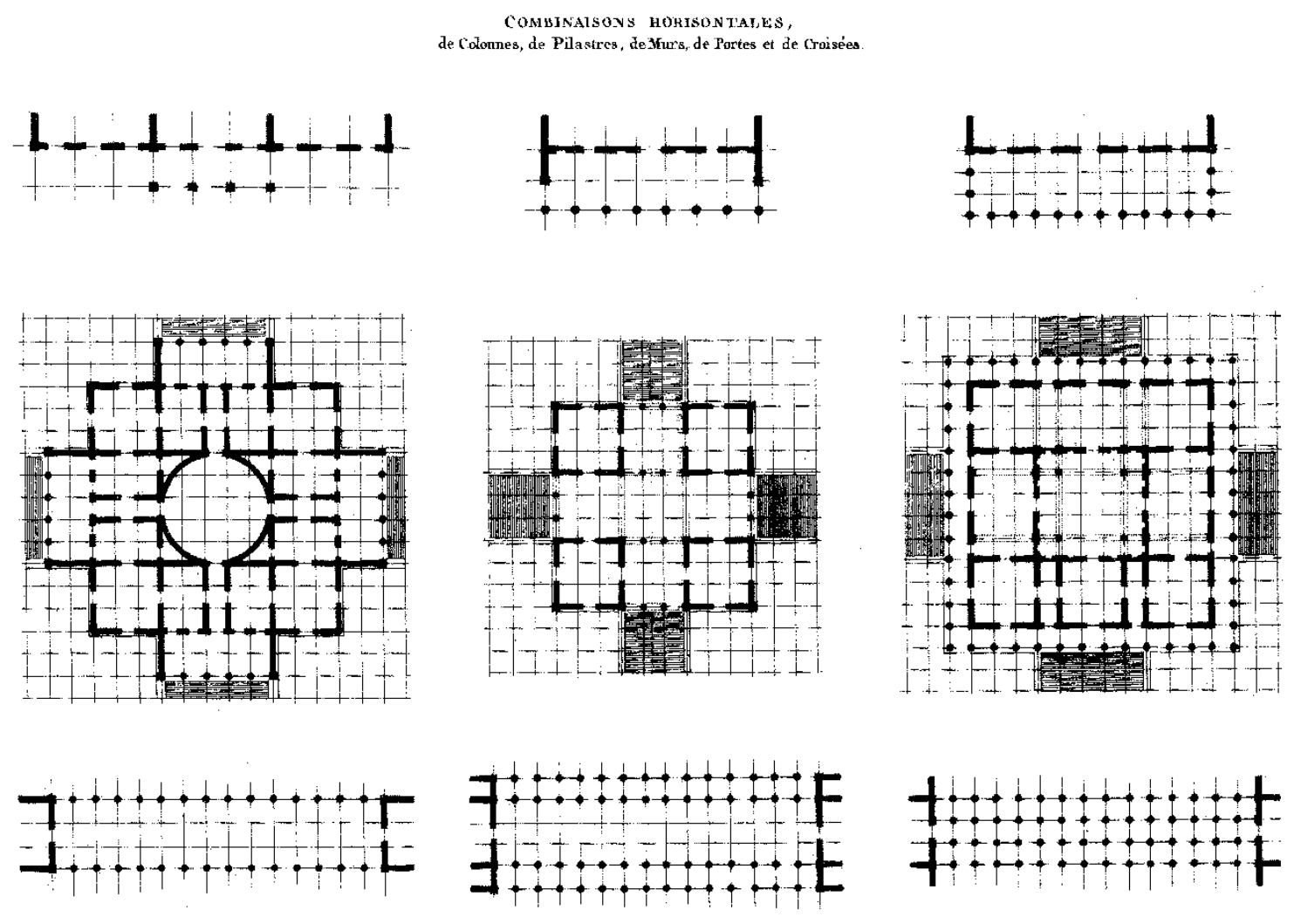

Figure 2. The visible "taxis" in Durand's plans: Précis of the Lectures on Architecture vol.1, Part II Composition in General, Plate 1. (Durand, [1802] 2000).

Taxis is ideational, representational and visual. It is a matter of formulation and formation on the way to perfection. According to Vitruvius, taxis is operated through certain forms of expression which are ichnographia, orthographia, and scenographia (Vitruvius, 1960, Book I, Chapter II). The idea 
of the building becomes embodied through these forms of expression. The lines, yet to be embodied, of taxis that give order to the composition become embodied with lines of elements, or genera as Tzonis and Lefaivre call them. Ichnographia demands the competent use of compass and rule to get the outlines of the surface that the building will be laid upon. It is the picture on the ground plane, or the ground level, on which we see the figure as naturally standing. Thus ichnographia is the representation of the base, or plane of something in the section when it is parallel with the ground plane (Marolois, 1629). Orthographia corresponds to elevation as we know it and as indicated in Morgan's translation of Vitruvius, it is a picture of the front of a building, set upright and properly drawn in the proportions of the contemplated work. It can rather be defined as the picture of the front or side of a building, edifice or body that is directly opposite the eye and also called the profile. Scenographia is a version of perspective that is a method of shading of the front and the retreating sides with the correspondence of all lines diminishing towards the background and meeting at the center of a circle (Vitruvius, [1st Century BC] 1960; Marolois, 1629).

Although it was obvious that for Vitruvius, the composition or the idea of building is ordered with lines of taxis embodied through the triad of ground plan, elevation and perspective, Alberti states the line as the prime constituent of architecture. He argues that architecture is comprises two parts, lineamenta and structura and makes lineamenta the subject of his first book in De Re Aedificatoria ([1452] 1988, pp. 7-32). Rykwert et al. translate lineamenta as "lineaments" which encompasses "lines", "linear characteristics", and so by implication "design" (1988, pp. 422-423). Alberti draws a fundamental distinction between lineamenta and structura in the first book. For Alberti and the art of building, design necessarily precedes construction and derives from the mind while construction derives from material, and thus nature, and is mediated by the skilled craftsman, yet lineamenta and structura are interdependent. Alberti explains the conceptual, substantial, and operational character of lineaments as follows:

All the intent and purpose of lineaments lies in finding correct, infallible way of joining and fitting together those lines and angles which define and enclose the surfaces of the building. It is the function and duty of lineaments, then, to prescribe an appropriate place, exact numbers, a proper scale, and a graceful order for whole buildings and for each of their constituent parts, so that the whole form and appearance of the building may depend on lineaments alone ([1452] 1988, 7).

It is impossible to define that line is the ultimate order in architecture better than Alberti. Lineaments are made up lines, solely lines, which are conceived in the mind and perfected in the intellect and imagination to provide order for architecture. Line is the smallest unit of lineaments that Euclidean geometry indicates has length but no thickness. A line exists only in mind; it is not physical. The lineament is rather a complex geometrical configuration although it has not a clear geometric definition. Like lines, lineaments are linear, but their eventual aim to enclose a figure implies that the two sides of the line are different, as inside and outside. Lineaments are lines without bodies yet they determine the bodily fragments and affect the bodily expression of a building.

It is not a coincidence that Alberti was the one who presented first citations of a call for a change in drawing techniques that architects apply. Alberti singled out the conflict between drawings that 
simulate vision (the painter's task, according to Alberti) and those that should provide accurate measurements for builders, and from that point onwards architects were obliged to choose between what have been called central and parallel, or, perspective and orthographic projections. In $D e$ Pictura (1435), Alberti set out the geometrical principles of the central perspective, yet he steered architects away from their use, or suggested they be used only with great care since such perspectival drawings do not provide the precise measurements required for architectural design. He suggested the geometrical drawings that architects should employ in plans and elevations, while Raphael added a definition of the "section" as a means of rendering the inside of the building (See, Lotz, 1977; Ackerman, 2002).

It is possible to claim that Alberti's prescriptions for architectural drawings in his treatise on painting (1435), have provided the basis for his conceptualizations of lineaments in his work on the art of building (1452). He knew the strength and the weaknesses of line for architecture thus, he abandoned the third form of expression that Vitruvius suggested. Alberti opposed the longestablished rules that predominated among Italian architects to represent the building in perspective, and argued that representation in perspective was to be left to the painters. Taxis was not to be performed in perspective but rather on the plan and elevation. Architects had to create their drawings orthogonally so that proportions were preserved and measurements could be taken from them.

The analytical manifesto of Andrea Palladio, I quattro libri dell'architectura (The Four Books on Architecture, 1570) is an important documentation on the relationship between design and drawing. Palladio constructs general solutions to architecture with only orthogonal drawings. The drawings in his analytical documentation do not present already constructed examples but rather the ideals of the architect. Discovering the power of drawing as a generative and formative tool besides its analytical, depictive and descriptive nature, Palladio utilized orthogonal projection as a means of formulating geometrical order, which breeds schematic and diagrammatic representations of the relationality between the building and its architectural elements. ${ }^{1} \mathrm{He}$ intended to express that there were "ideals" based on certain principles that transcend his own buildings.

\footnotetext{
1 Rudolf Wittkower claimed that Palladian villas are "derived from a single geometric formula" (1973, 68). See, Wittkower (1973), Architectural Principles in the Age of Humanism, New York: Van Nostrad Academy Editions: St. Martin Press.
} 

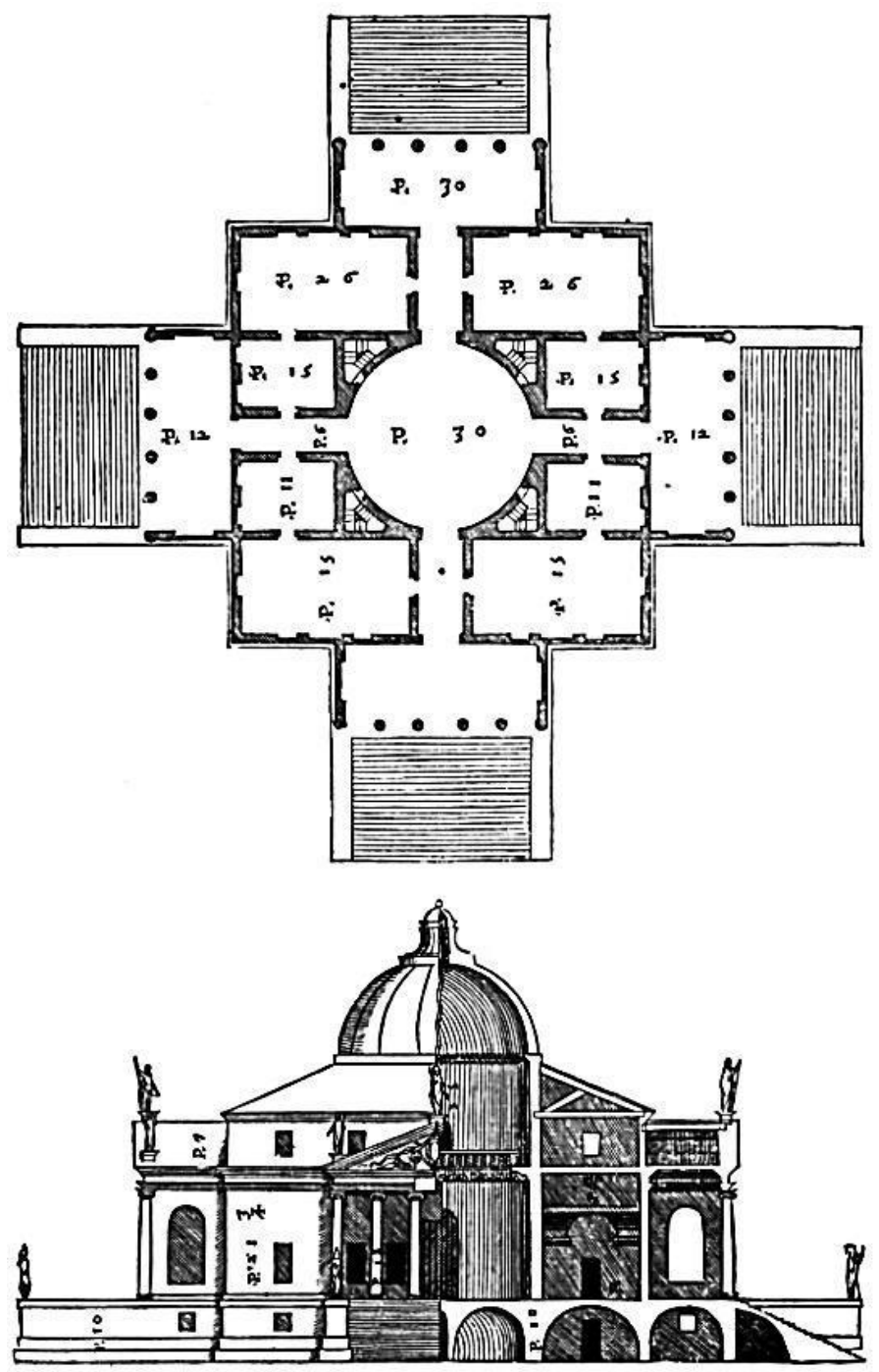

Figure 3. Plan and Elevation/Section of the Villa Rotonda by Andrea Palladio, 1570.

(Blau and Kaufman, 1989, p.161)

Palladio mastered the technique of orthographic projection and achieved a coherent understanding of architectural space by interlocking the three types of orthogonal drawings - plan, section and elevation. Robin Evans examines Palladio's famous plate containing the plan and an elevation/section of the Villa Rotonda (Figure 3). Palladio's plate provides an illustration of the "maximum service" that the orthographic set achieves both in the construction of architectural ideals and in the representation of architectural space. Evans (1995, pp. 118-119) provides a clear explanation of why forms designed following the classical ideal were "economical within the confines of the technique" of representation and resulted in powerful expressions with maximum information:

The three drawings are not just plan, elevation, and section, but ground plan, front elevation, and axial section. That is why in most classical architecture, design and building are in a near perfect accord. Maximum descriptive power is obtained at minimum price - 
a good bargain, so long as what is required is frontal, symmetrical, axial, and predominantly orthogonal (Evans, 1995, p. 119).

Apparently what has come to be known as glorious Orders is relatively a small part of Classical Architecture and its systems of ordering. The term order obviously meant something else for Vitruvius and for Alberti. What was order for Classical paradigm, and arguably for Vitruvius, for Alberti or for Sebastiano Serlio, is bluntly defined by John Summerson as:

An 'order' is the 'column-and-superstructure' unit of a temple colonnade. It does not have to have a pedestal and often does not. It does have to have an entablature (columns are meaningless unless they support something) and the cornice represents the eaves of the building finishing off the slope of the roof $(1963$, p. 9).
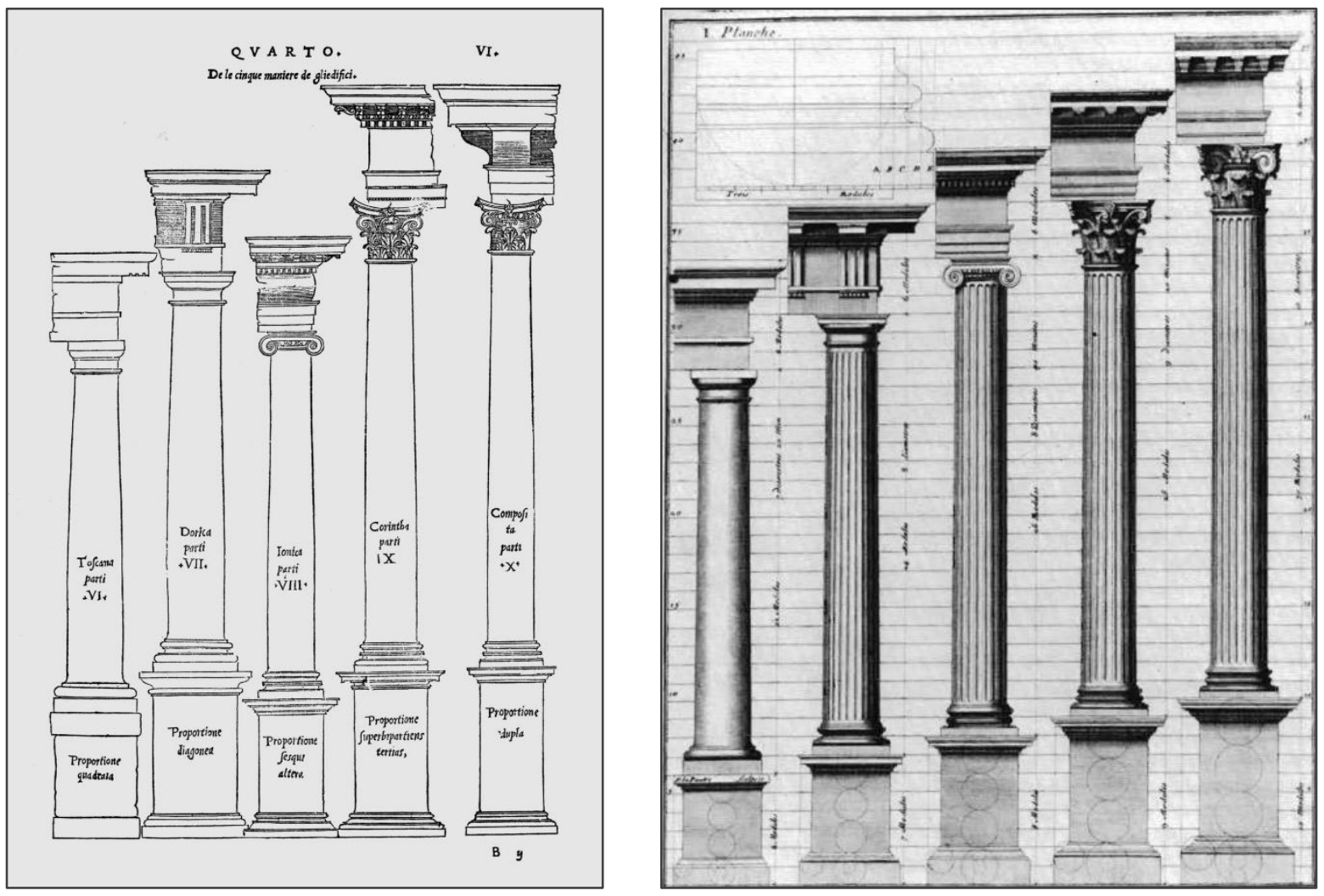

Figure 4. (left) Classical Orders by Sebastiano (Tutte l'opere d'architettura et prospettiva, Libro Quarto, 1584); (right) Classical Orders by Claude Perrault (Ordonnance for the Five Kinds of Columns after the Method of the Ancients. [1683] 1993, p. 95).

The "poetics of order" that Classical Architecture employed was highly comprehensive than the exaggerated reputation that "the column-and-superstructure" gained. Order is understood here in its most basic definition as identified with taxis or as sustained by lineaments - without the mystification of classical tradition in architecture. It was beyond the codes of a specific style that can be analyzed from, learned and applied in the design of future buildings. The principles of design could be perfectly deducted from the architectural object and its representations since architectural principles were set and executed through the medium of drawing itself. Following the framework 
provided by Tzonis and Lefaivre, the logic of composition was constructed on drawings, thus taxis, genera, and symmetry were visible features of the architectural object represented in the drawings. Even without knowing these operational and formal devices defined by the classical ideal, it is possible analyze and deduct these devices as means of order by using the very medium of orthogonal drawing. In other words, the orders that generate and control the architecture were established with(in) drawing.

\section{DISPLACING ORDERS: LINES TO DESIGN BODIES}

Modernism, above all the pretentions it had, was an attempt to wipe the slate clean, to break from the historical continuity of the previous centuries which has come to be known as the classical paradigm. Primarily, modernism was thought to be a rupture with the continuity of classicism. Modernism expressed this rupture both on the object and the processes of the object's making. Rejection of, in other words abstraction from, the historical precedent determined the object of architecture as architecture itself, and this severance from history turned Modern Architecture into "a style which represents and symbolizes history, in which case history is not deterministic" (Colquhoun, 1981, pp. 17-18).

By separating the architectural object from the contingencies of the historical context, Modern Architecture managed to carve out a level of architectural abstraction that led to the concentration of form. The object of architecture had to be produced following certain standards and rules, and thus had to be autonomous in constructing an international language. When architecture is redefined from the rules within, it possesses a meaning that advocates propagation based solely on form. "Architectural form," says Michael Hays, "is understood to be produced in a particular time and place, of course, but the origin of the object is not allowed to constrain its meaning" (1984, p. 16). In other words, Modern Architecture accepted that meaning in architecture is not dependent on the memory of its own past.

Modern Architecture severed itself from the past, and thus achieved an architectural abstraction, which can be represented by a tabula rasa, enabling concentration on the architectural object itself. As a result, the conditions for generating an abstract(ed) object are codified over form. The notion of abstraction also influenced the visual qualities of the object. In other words, abstraction for Modern Architecture not only implied the severance of the architectural object from the historical context, but also acquired a strong meaning with emphasis on the purification of form. Concentration on the object itself necessitated the stripping of its form of all applied ornamentation and preconceived practices of history. In doing so, compositions of primary forms were ordered by means of geometry, providing an understanding of proportions, references and relations, which radically shifted the "poetics of orders" in Classical Architecture.

The architectural object of both classicism and modernism contains the idea of original perfection. The significance of the object was understood in reference to simple type forms. In the classical paradigm these type forms were ideal and necessarily coming from nature, characterized by symmetries, central axes, and, as last but not the least, highly dominated by a hierarchy of elemental parts. In the modern, the type forms were platonic and abstract, characterized more easily be 
references to dynamic, asymmetric, mechanistic structures than the hierarchical types of the classical.

As the only modern architect who prescribed rules for architecture $^{2}$ (Colquhoun, 1981, p.51), Le Corbusier is a critical figure to trace the continuities from Classical Architecture. The well-known break with the history becomes questionable with the conceptualizations and practices of Le Corbusier. One can see the process by which the traditional language of architecture is transformed into a new language in Le Corbusier. In this way, the architecture of Le Corbusier does not present a rupture with the continuity of classicism but rather maintains its links with the past. Alan Colquhoun claims that nothing shows the "moment of transition" (1981, p. 13) from classical forms to the forms of a new architecture more clearly than Le Corbusier's "Five Points". Colquhoun (1981) assesses "Five Points" as transformations of the classical architectural vocabulary. He suggests that the rules which Le Corbusier prescribed in his "Five Points", each of which takes its departure from an existing practice and proceeds to reverse it. Colquhoun discusses Le Corbusier's creative process as a "displacement of concepts" (1981, pp. 51-66) - in other words, a process of reinterpretation. The change in the arrangement and interpretation of classical elements occur in the form of reversals and transformations. Colquhoun explained "displacement of concepts in Le Corbusier" as followed:

The use of pilotis is a reversal of the classical podium; it accepts the classical separation of the piano nobile from the ground but interprets this separation in terms of void rather than mass. The fenetre en longueur is a contradiction of the classical window aedicule. The roof terrace contradicts the pitched roof and replaces the attic story with an open-air room. The free façade replaces the regular arrangement of window openings with a freely composed surface. The free plan contradicts the principle by which distribution was constrained by the need for vertically continuous structural walls and replaces it with a free arrangement of nonstructural partitions determined by functional convenience (1981, p. 51).

Kenneth Frampton assesses the compositional method adopted by Le Corbusier as "deconstructive/reconstructive" (1981, p. 9). He claimed it was Le Corbusier's strategy of inversion that enabled him to reinterpret classical paradigm in such a way as to open them toward the body of modern forms. The new order was sustained by primary forms as the executer of the practice of modern design and geometry was the regulator of the relations between primary forms. Admiring the precision of mathematics and the directionality of geometry, Le Corbusier refers to "regulating lines" ([1923] 2007, p. 86):

Of the fateful birth of architecture.

The obligation to order. The regulating line is a guarantee against arbitrariness. It brings satisfaction to the mind.

The regulating line is a means; it is not a formula. Its choices and its expressive modalities are integral parts of architectural creation.

\footnotetext{
${ }^{2}$ Colquhoun credits Leonardo Benevolo with the suggestion that Le Corbusier was the only modern architect to prescribe rules for the new architecture. See, Leonardo Benevolo's History of Modern Architecture (1971).
} 
The means of guaranteeing order in Modern Architecture was determined by the "regulating lines." Although the sources and references of the architectural ideals have radically shifted, the validity of obligation to order from classicism until modernism is unquestionable. Yet, what is more significant is the unchanging dedication to line as the ultimate agency to structure and sustain order. Vitruvius' "taxis" and Alberti's "lineaments" were not abandoned but transformed into the "regulating lines" of Le Corbusier. This continuation was also prevalent in the practices of drawing. The concentration on the geometrically controlled abstract object led to the emergence of the orthographic drawing as the ultimate system of design and representation of architecture in modernism. Modern Architecture, and thus orthographic drawing, conceive and depict the abstract object as being assembled out of geometrical forms according to the principles of geometrical relations. The practice of regulating lines, or rather "the projection lines" as they become operational in the "translational space" (Evans, 1989) of orthographic projection, secured the presence of order. Diana Agrest explains the drawing's becoming into design by focusing on the practices of Le Corbusier within which he internalized geometry as the ultimate constituent of design and drawing:

Geometry, for example, had acted as an internal code for formal control from the classical period of Greek architecture. It had not, however, functioned as the provider of the formal vocabulary itself, geometric regulating lines being the "invisible" elements in the construction. For Le Corbusier, however, geometry became not only an instrument of formal control, but also the provider of the formal vocabulary itself in two and three dimensions. The instrument (tool) for representation, that is, drawing, became first the project itself, and then the construction, without alteration (Agrest, 1998, p. 204). 

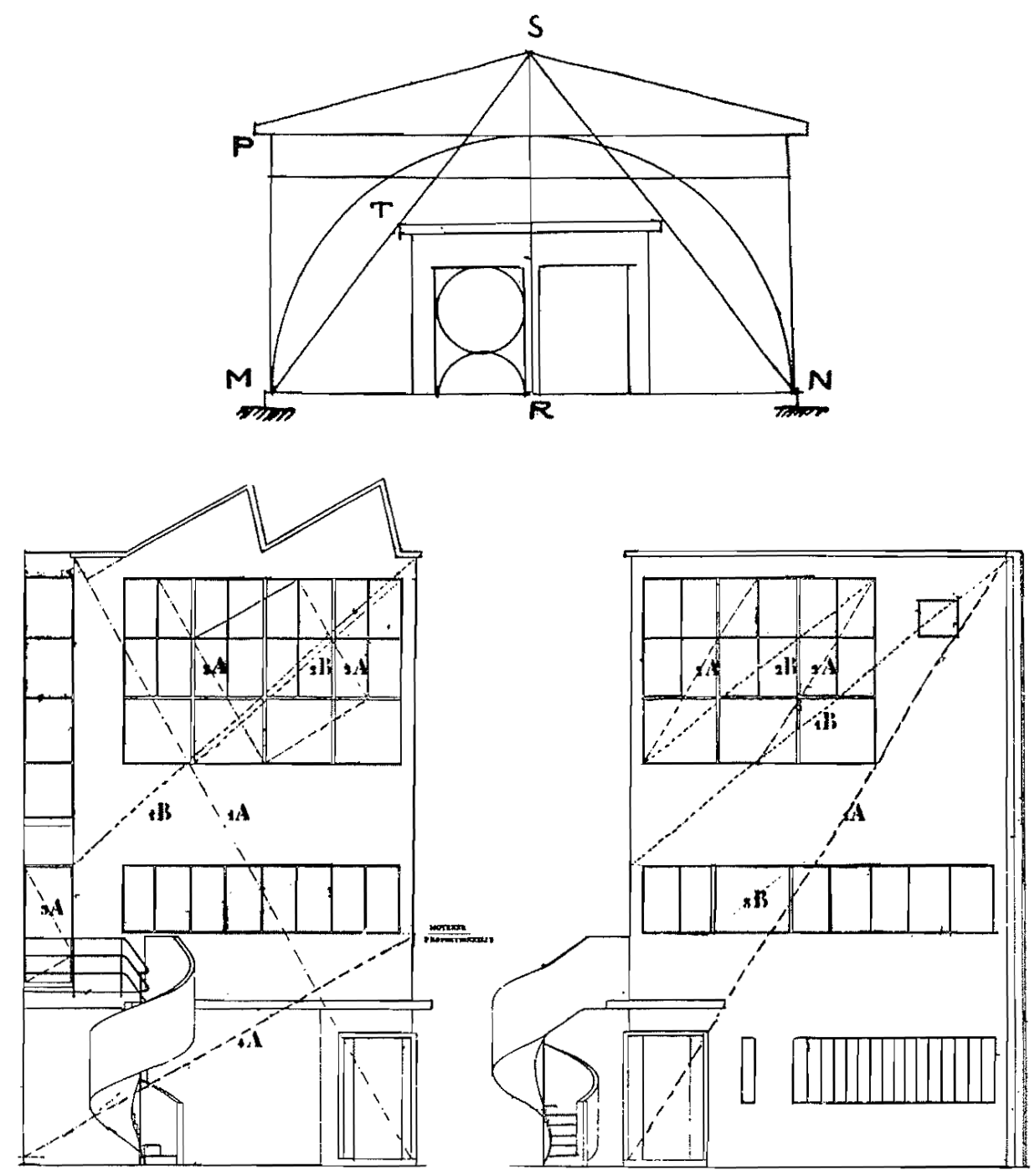

Figure 5. Regulating lines practiced by Le Corbusier (Le Corbusier, [1923] 2007, pp. 131-144).

One of the three constituents of the orthographic set, the plan has gone beyond being a mere illustration and became an architectural tool for creation in Modern Architecture. A plan is usually considered as a horizontal cut, and is actually a section in nature, drawn as the object's projection onto a plane assumed to intersect at a particular vertical position. In Classical Architecture, the plan was not just a plan but it was the plan of the ground floor, and actually a "non-existent footprint" (Ackerman, 2002, p. 196). In Modern Architecture, however, the plan has become a confrontation of architecture with its function. Modern Architecture achieved an apprehension of the plan to be accepted as the ultimate order dependent on the laws of practical distribution of spaces. Especially Le Corbusier acknowledged plan as the method of constructing a system rather than just an expression or projection of an idea. The plan has been considered as a means of design that enables the visualization of architectural creation. It was actually a field of experimentation. Starting the design process by the plan was not incidental for Le Corbusier. In Vers Une Architecture, he expresses his devotion to the plan ([1923] 2007, p. 86): 
The plan is the generator.

Without a plan, there is disorder, arbitrariness.

The plan carries within the essence of the sensation.

The great problems of tomorrow, dictated by collective needs, pose the question of the plan anew.

Modern life demands, awaits a new plan for the house and for the city.



Figure 6. Plan (at the ground level) of Villay Savoye by Le Corbusier.

(Oeuvre complète vol. I 1910-1929, p.186).

Le Corbusier used plan as the generator of design through which he constructs an ordered system of spaces requiring different expressions, dimensions and functions. He uses this particular type of orthographic drawing not only to represent a specific aspect of the building but actually as a means of design that projects a new building. Colquhoun makes an analogy between the Cubist paintings and Le Corbusier's plans to explain the intricate structural system "designed" by the drawing:

The principle is closely related to the procedures of Cubism, in which a representation must include all the space within the pictorial volume, and not merely the space between objects. Just as a Cubist painting is a description of the structure of the pictorial space, so Le Corbusier's houses are descriptions of the structure of the architectural space (1981, p. 62). 
Vitruvius, Alberti and Le Corbusier were all codifiers of architectural ideals. The trigger behind this obsession with the codification was the desire of order. Architecture had to be codified according to specific origins either tied exclusively to the authority of the ancient texts of presumably divine origin (the nature) or subjected to the autonomy of a hypothetical break with the history (the abstract). Although the origins of order have shifted, the agency through which the order is sustained has always been the concept and the practice of line.

\section{BREAKING ORDERS: LINES TO DESTRUCT BODIES}

The reduction of architecture to pure functionality and thus the reduction of architectural form to pure geometry was, in fact, a fake abstraction. In 1960s, it was criticized to be another attempt to provide correspondence between architecture and reality. In this sense, functionalism merely replaced the orders of classical composition as the starting point of architectural design. Undecorated, functional objects were no different than the elements chosen from antiquity. They were simply stripped down versions of classical forms referring to a new set of givens. Modernism turned out to be yet another stylistic conclusion based on a positivism not grounded on the rules of nature but rather on the science and technology. From this perspective Modern Architecture can be seen as continuous with the architecture that preceded it. Trying to reduce architectural form to its essence, to its formal purity, Modern Architecture assumed to relieve the form from its historical burdens and thus re-assess it according to a non-referential objectivity.

A column without a base and capital was thought to be an abstraction. Thus reduced, form was believed to embody function more honestly. Such a column was perceived to be more like a real column, the simplest possible load-carrying element of all times. However, the column faced with a moment that it did not even have to touch the ground. It became merely a linear element. This was the moment that architecture witnessed an epistemic break. The ground that the longestablished paradigms of architecture have been based upon for centuries is fundamentally slipped away with the destruction, or as it is stylistically known, deconstruction of bodies.

Order is questioned. Formalism is exaggerated. In the end, the architectural object, once stripped from all historical references, is also distilled from its function. Thus, architectural form is revealed as a "place of invention" (Eisenman, 1970a, pp. 1-5) rather than as a subservient representation of antiquity or as a strictly practical device. Architecture is accepted to be universal - neither eternal nor international - yet, momentary. Withdrawal of order shifted the obsession with the architectural object as an ideal perfection into a concentration of processes that produce it. In other words, the architectural object is replaced with a diagram of its formative processes. 

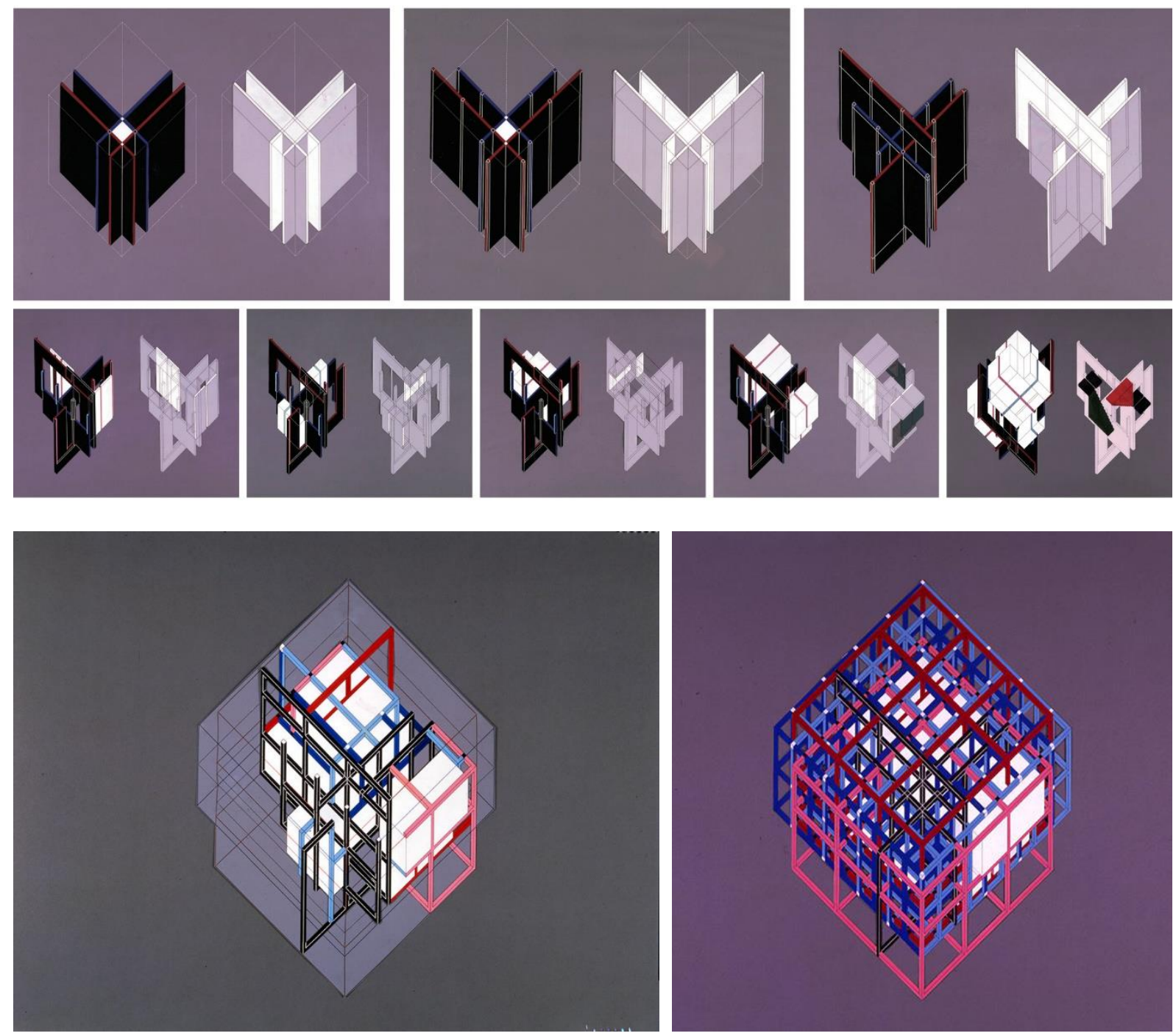

Figure 7. Formative processes of House VI by Eisenman.

(https://eisenmanarchitects.com/House-VI-1975. Last accessed in July 8, 2019)

The architectural object, of which the external determinants of its forms are removed and solely challenged by its inherent aspects, leaves architecture in suspense. As one of the leading figures of this new approach, Peter Eisenman aims at shaking our normal sensibilities concerning built form. Eisenman suggested "to pull apart the one-to-one relationship between structure, form, meaning, content, symbolism, etc. so that it is possible to make many meanings" (1991, p. 34). For Alberti the separation of lineamenta from structura was the foundation of his theory but structure gained a reputation as an abstract content of form, which challenged Albertian paradigm of design. Eventually, structure did not only depart from its materiality but also from its visual and sensual properties and even recognized as a "deep aspect concerned with conceptual relationships which are not sensually perceived; such as frontality, obliqueness, recession, elongation, compression and shear, which are understood in the mind" (Eisenman, 1971, pp. 38-39). For Eisenman, all formal relationships and spatial transformations of his designs were the result of what he regards as the inherent logic of the forms themselves. A problem of somewhat different order is created by 
Eisenman's desire to have us perceive an intricate relationship between what he calls "the actual structure" and "the implied structure". He argues that the interstice between actual structure and implied structure reveals a "deep structure" (See, Eisenman 1970b; 1975; 1999; 2006), which was not an order but it was surely a rule system for form; a system that does not actually construct but rather instantiate form.

With a concentration on the formal and structural aspects of architecture, Eisenman proposed that the architecture could be distilled by "reducing or stripping away the meaning and function of the architectural object" (1987, p. 177). By referring to his designs as "cardboard" architecture, Eisenman presented a series of houses, which can be assessed as the first experiments of Deconstructionism. From these houses, House I took the form of "reducing the apparent structure to non-structural elements," whereas House II took the form of "exaggerating the structure through an explicit, non-functional redundancy” (Eisenman, 1987, p. 174).

To explore and convey his ideas on deep structure, Eisenman chooses to use series of axonometric projections. The selection of axonometric drawing is not accidental for him to reveal this unusual kind of structure. For Eisenman to explore the possibilities of form in-between actual and implied structures, axonometric projection provided the perfect medium in-between the real and the ideal, negating neither depth nor geometry. The cover of the critical collection of his work entitled "Houses of Cards" is also occupied by an axonometric projection that represents a cube with transparent and colored layers, which enhances ambiguous readings in the perception of the space exists within. Emphasizing the significance of axonometric projection for Eisenman, Robert E. Somol claims that:

In contrast to the other dominant mode of three-dimensional drawing, the central projection or perspective of Renaissance humanism, the axonometric favors the autonomy of the object by conveying measurable or objective information over the distortion created by a vanishing point oriented to the viewing subject...the axonometric simultaneously renders plan, section, and elevation, thus again collapsing the vertical and horizontal... unlike Corbusier's 'regulating lines' - geometric descriptions appended to their objects after construction - the three-dimensional device of the axonometric enables analysis and object to become congruent (1999, pp. 15-16). 


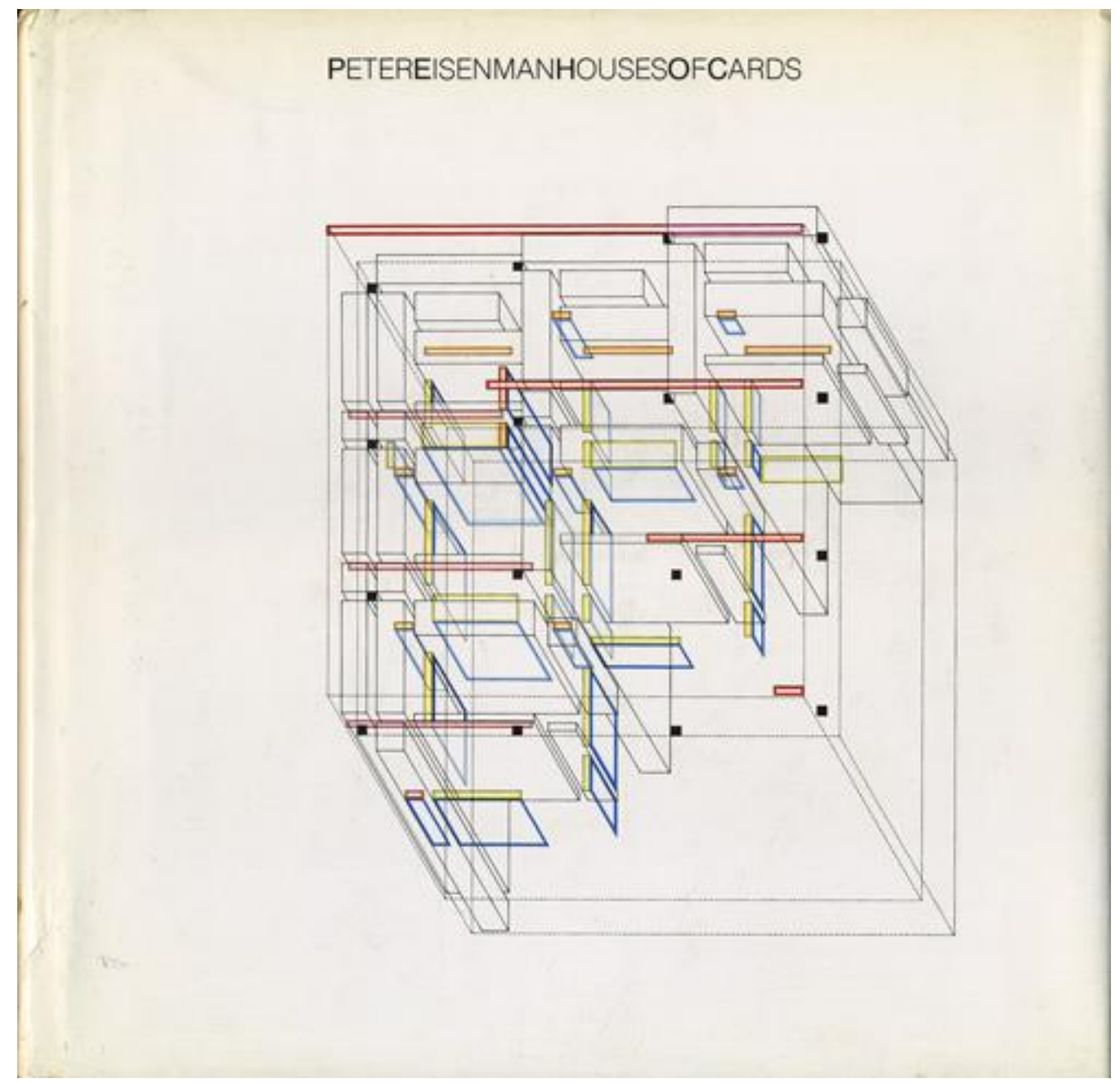

Figure 8. Book cover of Houses of Cards by Eisenman (1987).)

Axonometric projection extends beyond the limitations of perspective and orthographic projections; by abolishing the petrified spectator and the distorted dimensions of the former and by exceeding the flatness of the latter. However, this medium, which was conventionally practiced as an objective means for representing the object and thus its objectness in three-dimensions is transformed into a subjective, interpretive, deconstructive and tentative space of investigation by Eisenman. Yet again, it is the inherent instability of the line that enables architecture to suspend itself. Eisenman's notions of implied and deep structures curiously and specifically have a graphic dimension. His formative processes and deep structures become visible in axonometric projections by the virtue of lines without bodies.

\section{WITHDRAWING ORDERS, DRAWING ARCHITECTURE}

Drawing, including all different modes and techniques it acquired, constitutes a repository of architectural thinking and provides a visual survey of architectural design. Among all the registers through which architecture is produced, drawing has been the key element as a methodology of architectural analysis and production, a tool for learning and knowing, a source for accumulation 
and dissemination of knowledge, and a work of architecture in its own right. The discipline ${ }^{3}$ of architecture, formed and developed heavily around the augmented dependence between drawing and design, has been challenged by digital technologies and computational design within the last few decades. Detaching architecture from its representations caused a fundamental deflection in architectural design and thus in the production of architectural knowledge.

Architecture and its disciplinarity heavily depend on the historical formation of critical vocabularies. Words and their theoretically, historically and contextually associated fellows form critical vocabularies through the changing idealizations of architecture to reflect epistemological tendencies, stylistic manifestos, discursive regimes, means of production, aesthetic appeals and so on. At the moment that architecture struggles to maintain its links with the accumulated body of vocabularies, this paper suggests a critical look at the origins and originals that challenged their premises. Anchoring itself to the vicissitude of the term order, the study unfolds the shifts in its meanings, practices and questionings. It cultivates a critical reading of architectural drawing as a means of architectural production, which is not merely the representation of a not-yet-architecture but significantly the writing of the discipline of architecture.

Order is no longer a question or desire as architecture expands its lexical field to include predominantly the terminologies of digital media, computer sciences, programming languages, software development, etc. and imports concepts from biology and evolution theories. This study assesses the interwoven histories and meanings of drawing and design, and so does their vocabularies, fundamental for the production of architectural knowledge. It aspires an acknowledgement of line as an architectural substance that is powerful in the definition, production and critique of architecture.

As architecture contrives disorderly ways and processes of design in the loss of visuality, logic of composition no longer require order for architecture. Albertian separation of lineamenta and structura is obsolete; Evans' translational spaces ceased to exist; and Eisenman's deep structures become volatile. Lines with/out bodies no longer order. They refuse to synthesize into bodies. The order is broken. Bodies are destructed. Architectural object becomes futile. Yet, Evans re-claims the authority of drawing over building for architecture. Focusing on Daniel Libeskind's Chamber Works, he associates drawing with lines without bodies to "architecture without building" (Evans, 1998, p. 487). Without representing any architectural object beyond itself, Evans claims that Chamber Works moves architecture from building to drawing:

[D] rawing once again the fountainhead of architectural creation. In another way it is a truncation. Architecture, which has always involved drawing before building, can be split into prior and subsequent activities: design and construction. The building can be discarded as an unfortunate aftermath, and all the properties, values, and attributes that are worth keeping can be held in the drawing; perhaps a better way of putting it would be to say that they retract back into the drawing.

\footnotetext{
3 The understanding of discipline here is based on the definition of Stanford Anderson as "a growing body of knowledge unique to this field; it cannot be reduced to the constructs of other fields" (1987: 7).
} 
And it is true that the imaginative work of architecture has for a long time been accomplished almost exclusively through drawing, though manifested almost exclusively in building. The great peculiarity of architecture as a visual art is the considerable distance between the process of composition and the thing being composed. By truncating architecture and disposing of building, an intimacy between a way of designing and the thing designed is achieved (Evans, [1984] 1998, p. 488).

\section{REFERENCES}

Ackerman, J. (2002). Origins, Imitation, Conventions: Representation in the Visual Arts. Cambridge, MA: The MIT Press.

Agrest, D. ([1976] 1998). Design versus Non-Design. In K. Michael Hays (ed.), Architecture Theory since 1968 (pp. 198-213). Cambridge, MA: The MIT Press.

Alberti, L. B. ([1452] 1988). On the Art of Building in Ten Books. Translated by Joseph Rykwert et. al. Cambridge, MA: The MIT Press.

Anderson, S. (1987). On Criticism. Places 4(1), 7-8.

Benovolo, L. (1971). History of Modern Architecture. Cambridge, MA: The MIT Press.

Colquhoun, A. (1981). Displacement of Concepts in Le Corbuiser. In Essays in Architectural Criticism: Modern Architecture and Historical Change (pp. 51-66). Cambridge, MA: The MIT Press.

Durand. J.N.L. ([1802] 2000). Précis des leçons d'architecture données à l'École royale polytechnique / Précis of the Lectures on Architecture. Introduction by Antoine Picon, translated by David Britt. Los Angeles: CA: Getty Publications.

Eisenman, P. (1970a). Notes on Conceptual Architecture: Towards a Definition. Design Quarterly $78 / 79,1-5$.

Eisenman, P. (1970b). From Object to Relationship: the Casa del Fascio by Terragni. Casabella, 344 (January), 38-41.

Eisenman, P. (1971). From Object to Relationship II: Giuseppe Terragni, Casa Giuliani Frigerio. Perspecta 13/14, 36-65.

Eisenman, P. et al. (1975). Five architects: Eisenman, Graves, Gwathmey, Hejduk, Meier. New York: Oxford University Press.

Eisenman, P. (1987). Houses of Cards. New York: Oxford University Press.

Eisenman, P.(1991). Strong Form, Weak Form. In Peter Noever and Regina Haslinger (eds.), Architecture in Transition: Between Deconstruction and New Modernism (pp. 32-43). Munich: Prestel.

Eisenman, P. (1999). Diagram Diaries. New York: Universe Publishing.

Eisenman, P. (2006). The Formal Basis of Modern Architecture. Lars Müller Publishers.

Evans, R. (1989). Architectural Projection. In Eve Blau and Edward Kaufman (eds.), Architecture 
and Its Image: Four Centuries of Architectural Representation: Works from the Collection of the Canadian Centre for Architecture (pp. 19-35). Montreal: Centre Canadien d'Architecture/Canadian Centre for Architecture; Cambridge, Mass.: Distributed by the MIT Press.

Evans, R. (1995). The Projective Cast: Architecture and Its Three Geometries. Cambridge, MA: The MIT Press.

Evans, R. ([1984] 1998). In Front of Lines that Leave Nothing Behind. In K. Michael Hays (ed.), Architecture Theory since 1968 (pp. 480-489). Cambridge, MA: The MIT Press.

Frampton, K. (1981). Preface. In Essays in Architectural Criticism: Modern Architecture and Historical Change (pp. 1-10). Cambridge, MA: The MIT Press.

Hays, M. (1984). Critical Architecture: Between Culture and Form. Perspecta, 21, 14-29.

Le Corbusier. 1990. Oeuvre complète vol. I 1910-1929. Basel; Boston: Birkhäuser.

Le Corbuiser. ([1923] 2007). Vers Une Architecture / Toward an Architecture. Introduction by JeanLouis Cohen, translated by John Goodman. Los Angeles, CA: Getty Research Institute.

Lotz, W. (1977). Studies in Italian Renaissance Architecture. Cambridge, MA: The MIT Press.

Marolois, S. (1629). La Perspective contenant la théorie, practique et instruction fondamentale d'icelle. Amsterdam.

Palladio, A. (1570). I quattro libri dell'architectura. Venice.

Perrault, C. ([1683] 1993). Ordonnance for the Five Kinds of Columns after the Method of the Ancients. Intro. Alberto Pérez-Gómez. Trans. Indra Kagis McEwen. Santa Monica, CA: The Getty Center Publications.

Rykwert, J. et al. (1988). Glossary. On the Art of Building in Ten Books (420-428). Cambridge, MA: The MIT Press.

Serlio, S. (1584). Tutte l'opere d'architettura et prospettiva. Venice.

Somol, R. E. (1999). Dummy Text, or the Diagrammatic Basis of Contemporary Architecture. In Diagram Diaries (pp. 6-25). New York: Universe Publishing.

Summerson, J. (1963). The Classical Language of Architecture. London: BBC.

Türkay, Seray. (2011). The Orthographic Set: Making Architecture Visible. Unpublished Masters Thesis, METU.

Vitruvius, M. P. ([1st Century BC] 1960). Ten Books on Architecture. Translated by Morris Hicky Morgan. New York: Dover Publicaitons.

Wittkower, R. (1973). Architectural Principles in the Age of Humanism, New York: Van Nostrad Academy Editions: St. Martin Press. 


\section{ACKNOWLEDGEMENT}

This article benefits from the author's graduate research at Middle East Technical University (METU), Department of Architecture. The text includes references from the reader of the PhD method course "Arch 616 - Architectural Research II" (Spring 2013) conducted by Prof. Dr. Ayşen Savass in the PhD Program in Architecture at METU and from the author's master's thesis entitled The Orthographic Set: Making Architecture Visible.

\section{BIOGRAPHY OF THE AUTHOR}

\section{Seray Türkay Coşkun}

Seray Türkay Coşkun received her B.Arch (2008), M.Arch (2011) and Ph.D. (2017) degrees in Architecture from Middle East Technical University (METU), Department of Architecture, where she also worked as a research and teaching assistant between 2010-2017. After working as a parttime studio instructor at TED University Department of Architecture between 2017-2019, she received her position as an Assistant Professor in the same department. Her research fields include architectural design, design education, architectural drawing, representation and visuality, exhibition as research, and part/whole in architectural form. 